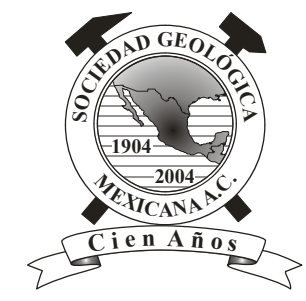

\title{
Corrigendum
}

\section{Ophthalmoplax (Decapoda: Brachyura: Portunoidea) from the late Campanian, Upper Cretaceous, of Colombia}

\author{
Walter Guzmán ${ }^{1}$, Hermann Darío Bermúdez ${ }^{1}$, Arley de Jesús Gómez-Cruz², \\ Francisco J. Vega ${ }^{3, *}$ \\ ${ }^{1}$ Grupo de Investigación Paleoexplorer, Calle 98bis 71D-20 Bogotá D.C. Colombia. \\ ${ }^{2}$ Universidad de Caldas, Facultad de Ciencias, Departamento de Ciencias Geológicas, Calle 65 No. 26-10, Manizales, Caldas, \\ Colombia. \\ ${ }^{3}$ Instituto de Geología, Universidad Nacional Autónoma de México, Ciudad Universitaria, Coyoacán, 04510, CDMX, México. \\ *vegver@unam.mx
}

After the paper by Guzmán et al. (2016) was published, an error related to the catalog numbers of the fossils specimens was pointed out. The codes UN-DG-CR-021 and UN-DG-CR-022 had already been used in the description of Colombian specimens of the lobster Meyeria magna M'Coy, 1849, in the publications of González-León (2016) and González-León et al. (2016), forcing us to replace these numbers. By mutual agreement between the authors, new catalog numbers were assigned by the Paleontological Collection of the Universidad Nacional de Colombia.

The correct catalog numbers are found below (corrections are in bold).

In 4. Material (p. 95). Two specimens are deposited in the Paleontological Collection of the Universidad Nacional de Colombia, Facultad de Ciencias, Departamento de Geociencias, Bogotá D.C., Colombia, under catalog numbers UN-DG-CR-031 and UN-DG-CR-032.

In Figure 3 caption (p. 97). Ophthalmoplax andina $\mathrm{n}$. sp., Lodolitas de Aguacaliente Formation, late Campanian. A) Dorsal carapace morphology, holotype UN-DG-CR-031. B) Dorsal carapace morphology, paratype UN-DG-CR-032 . Scale bars $=1 \mathrm{~cm}$.

In Figure 4 caption (p. 98). Line drawing of Ophthalmoplax andina n. sp., based on holotype UNDG-CR-031, sp. A) Bifid rostrum, B) Orbital spines, C) Posterolateral margin, D) Anterolateral margin, E) Protogastric region, F) Mesogastric region, G) Metagastric region, H) Urogastric region, I) Branchial lobes, J) Cardiac region, K) Metabranchial region, L) Hepatic region, M) Anterolateral spine, N) Epibranchial region, O) Mesobrachial region, $\mathrm{P}$ ) Lateral spine. Scale bar $=1 \mathrm{~cm}$.

In 5. Systematic Paleontology: Material (p. 98). Two small carapaces, holotype UN-DG-CR-031; paratype UNDG-CR-032.

In text Figure 5 (p. 99). Ophthalmoplax spp. from different localities and ages. A) Ophthalmoplax andina n. sp., holotype UN-DG-CR-031, upper Campanian, Colombia. B) O. minimus, upper Campanian, $\sim 76 \mathrm{Ma}$, Morocco. C-H) O. brasiliana, Upper Cretaceous of the Americas. C) Lower Maastrichtian, $70 \mathrm{Ma}$, Mississippi, USA. D) Lower Maastrichtian, $70 \mathrm{Ma}$, North Carolina, USA. E) Upper Maastrichtian, 66.8 Ma, Colombia. F) Upper Maastrichtian, $\sim 66.8 \mathrm{Ma}$, North Carolina, USA. G) Uppermost Maastrichtian, 66.2 Ma, Mexico. H) Uppermost Maastrichtian, 66.2 Ma, Mississippi, USA. Scale bars $=1 \mathrm{~cm}$.

In text Table 1 (p. 100). Measurements (in $\mathrm{mm}$ ) of holotype UN-DG-CR-031 and paratype UN-DG-CR-032 of Ophthalmoplax andina $\mathrm{n}$. sp.

In text Table 1 (p. 100). Holotype UN-DG-CR-031... Paratype UN-DG-CR-032.

\section{References}

González-León, O., 2016, Estudio taxonómico, ontogenético y de la estructura en la langosta fósil Meyeria magna (Decápoda, Mecochiridae) del Cretácico temprano: Universidad Nacional Autónoma de México, Cd. Mx., Master of Earth Sciences dissertation, $75 \mathrm{p}$. 
González-León, O., Patarroyo, P., Moreno-Bedmar, J.A., Nyborg, T., Vega, F.J., 2016, A new record and cuticular structure of Meyeria magna (Decapoda, Mecochiridae) from the lower Albian (Lower Cretaceous) of Colombia: Cretaceous Research, 57, 342-349.

Guzmán, W., Bermúdez, H.D., Gómez-Cruz, A., Vega, F.J., 2016, Ophthalmoplax (Decapoda: Brachyura: Portunoidea) from the late Campanian, Upper Cretaceous, of Colombia: Boletín de la Sociedad Geológica Mexicana, 68 (1), 93-103.
Manuscript received: July 14, 2016. Manuscript accepted: July 14, 2016. 